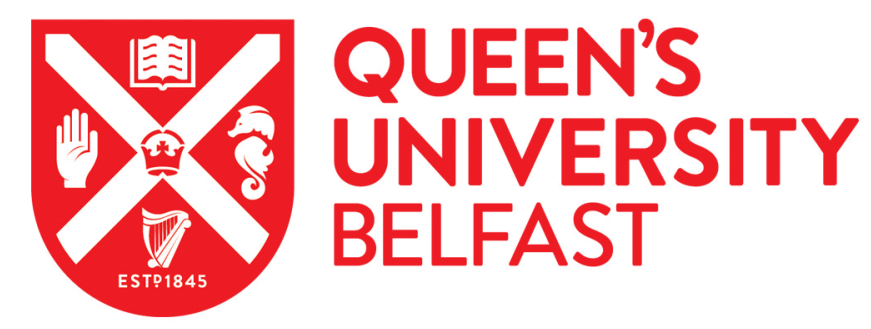

\title{
Degradation of benzo[a]pyrene in soil with arbuscular mycorrhizal alfalfa
}

Liu, S. L., Luo, Y. M., Cao, Z. H., Wu, L. H., Ding, K. Q., \& Christie, P. (2004). Degradation of benzo[a]pyrene in soil with arbuscular mycorrhizal alfalfa. Environmental Geochemistry and Health, 26(2), 285-293.

https://doi.org/10.1023/B:EGAH.0000039592.80489.e5

Published in:

Environmental Geochemistry and Health

Queen's University Belfast - Research Portal:

Link to publication record in Queen's University Belfast Research Portal

\section{General rights}

Copyright for the publications made accessible via the Queen's University Belfast Research Portal is retained by the author(s) and / or other copyright owners and it is a condition of accessing these publications that users recognise and abide by the legal requirements associated with these rights.

Take down policy

The Research Portal is Queen's institutional repository that provides access to Queen's research output. Every effort has been made to ensure that content in the Research Portal does not infringe any person's rights, or applicable UK laws. If you discover content in the Research Portal that you believe breaches copyright or violates any law, please contact openaccess@qub.ac.uk. 


\title{
Degradation of benzo[a]pyrene in soil with arbuscular mycorrhizal alfalfa
}

\author{
S.L. Liu ${ }^{1}$, Y.M. Luo ${ }^{1,3}$, Z.H. Cao ${ }^{1}$, L.H. Wu ${ }^{1}$, K.Q. Ding ${ }^{1} \&$ P. Christie ${ }^{2}$ \\ ${ }^{1}$ Soil and Environment Bioremediation Research Centre (SEBC), Institute of Soil Science, Chinese Academy \\ of Sciences, P.O. Box 821, Nanjing 210008, China \\ ${ }^{2}$ Department of Agricultural and Environmental Science, Queen's University of Belfast, Newforge Lane, \\ Belfast BT9 $5 P X, U K$ \\ ${ }^{3}$ Author for correspondence (tel.: +86-25-86881101; e-mail: ymluo@issas.ac.cn)
}

Received 17 February 2003 Accepted 18 August 2003

Key words: alfalfa, arbuscular mycorrhizal fungi, benzo $[a]$ pyrene $(\mathrm{B}[a] \mathrm{P})$, degradation rate, PAHs

\begin{abstract}
Mycorrhizal and non-mycorrhizal alfalfa (Medicago sativa) was grown in pots containing soil artificially contaminated with various levels of benzo $[a]$ pyrene $(\mathrm{B}[a] \mathrm{P})\left(0,1,10\right.$ and $\left.100 \mathrm{mg} \mathrm{kg}^{-1}\right)$. Soil and plants were sampled after 30, 40, 50, 60 and 90 days and compared with unlanted pots. The percentage of mycorrhizal root length colonized by Glomus caledoniun was not significantly affected by the addition of $\mathrm{B}[a] \mathrm{P}$ up to $10 \mathrm{mg} \mathrm{kg}^{-1}$ but was significantly lower at $100 \mathrm{mg} \mathrm{kg}^{-1} \mathrm{~B}[a] \mathrm{P}$ compared with low concentrations $(p<0.05)$. There was no difference in soil polyphenol oxidase and dehydrogenase activity among the controls and applications of 1 and $10 \mathrm{mg} \mathrm{kg}^{-1}$ of $\mathrm{B}[a] \mathrm{P}$. However, enzyme activities were significantly higher at $100 \mathrm{mg} \mathrm{kg}^{-1} \mathrm{~B}[a] \mathrm{P}$ compared with the other three treatments, and there was no mycorrhizal effect. Over a period of 90 days the concentration of $\mathrm{B}[a] \mathrm{P}$ in soil in which alfalfa was grown was significantly lower than in unplanted soil $(p<0.05)$. Degradation rates of $\mathrm{B}[a] \mathrm{P}$ added at 1,10 and $100 \mathrm{mg} \mathrm{kg}^{-1}$ without G. caledonium were 76,78 and $53 \%$, and with mycorrhizal inoculation were 86,87 and $57 \%$. The degradation rate in unplanted soil was significantly lower than in planted soil, and was significantly higher in medium- and low- $\mathrm{B}[a] \mathrm{P}$ treatments than in the high $\mathrm{B}[a] \mathrm{P}$ concentration tested. There is a possibility of enhancement phytoremediation of PAHs in rhizosphere soil with arbuscular mycorrhizal fungi.
\end{abstract}

\section{Introduction}

Polycyclic aromatic hydrocarbons (PAHs) are ubiquitous soil contaminants originating from natural and anthropogenic sources (Edwards et al. 1983; Wolfgang 2000). In general, these nonpolar and hydrophobic molecules with two or more benzene rings persist in the environment. The effect and fate of PAHs in nature are of great environmental and human health concern due to their carcinogenic, mutagenic and teratogenic properties (Wilson \& Jones 1993; Shaw \& Connell 1994) as well as their high concentrations and frequency of occurrence in the environment (Sims \& Overcash 1983; Jones et al. 1989) and high persistence due to low solubility and bioavailability
(USEPA 1985; Edwards 1988; Zaidi \& Imam 1999). Human exposure to PAHs can occur through different environmental pathways including internal absorption through food and water consumption (Edwards et al. 1983; Wild \& Jones 1992).

Recent studies have indicated that the rhizosphere of plants might play an important role in bioremediation of surface soils contaminated with toxic organic chemicals such as PAHs (Schwab \& Banks 1994; Günther et al. 1996; Reilley et al. 1996; Ryan et al. 2000). The effect of plant roots on the dissipation of organic pollutants has been attributed mainly to increased microbial numbers and selection of specialized microbial communities in the rhizosphere (Reilley et al. 1996; Banks et al. 
1999), but also to improved physical and chemical soil conditions, supply of root exudates for cometabolic processes (Yoshitomi \& Shann 2001), and increased humification and adsorption of pollutants increasing their bioavailability (Günther et al. 1996; Joelle et al. 2002). In contrast, naphthalene mineralization was found to decrease in vegetated microcosms (Watkins et al. 1994). In field experiments, growth and grain yield of maize were reduced in hydrocarbon-treated pots (Chaineau et al. 1996). Aprill \& Sims (1990) showed that the rhizosphere effect depended on plant species. Little is known about the relative contribution of roots or of specific rhizosphere microorganisms in the dissipation of organic pollutants in the rhizosphere. Investigations of rhizosphere microbial populations have usually compared plate counts of bacteria and fungi, and PAH-using bacteria from rhizosphere and non-rhizosphere soil (Lee \& Banks 1993; Qiu et al. 1994; Chaineau et al. 1996, 2000; Günther et al. 1996). Other rhizosphere inhabitants have not been considered.

Arbuscular mycorrhizal fungi are ubiquitous symbiotic microorganisms associated with plants of most families of angiosperms and gymnosperms (Harley \& Smith 1983). They play an important role in plant uptake of water, $\mathrm{P}$, and other nutrients (Mosse 1973). The AM fungi are of particular importance when plants are under environmental stress such as water or salt stress (Sylvia \& Williams 1992). In heavy metal polluted soils, AM fungi can protect plants against metal toxicity (Leyval et al. 1997), and the possible application of AM fungi for the remediation of heavy metal polluted soils has been discussed (Donnelly \& Fletcher 1994; Leyval et al. 1997). They also contribute to soil aggregation, thus improving soil structure (Miller \& Jastrow 1992).

Although AM fungi provide a direct link between soil and plant roots, very little is known about the interactions between organic pollutants such as PAHs and AM fungi, including the effect of PAHs on mycorrhizal colonization and the effect of AM fungi on plant growth and rhizosphere dissipation of PAHs in polluted soils. Recently, Cabello (1997) showed that mycorrhizal colonization decreased in hydrocarbon-polluted soils in comparison with an unpolluted soil, but no detailed description or soil analysis was given. The objective of the present study was to investigate the influence of PAHs on mycorrhizal colonization of plant roots and the possible role of AM fungi in enhanced degradation of PAHs in the soil.

\section{Materials and methods}

\subsection{Soil}

Topsoil $(0-20 \mathrm{~cm})$ was collected from Changshu Ecological Experimental Station, Institute of Soil Science, Chinese Academy of Sciences. The paddy soil was developed from lacustrine sediments in the Tai Hu Lake region. The soil was ground to pass a 2-mm plastic sieve. Selected properties were as follows: $\mathrm{pH}$ (in $\mathrm{H}_{2} \mathrm{O}$ ) 7.40; organic matter $36.3 \mathrm{~g}$ $\mathrm{kg}^{-1}$; total $\mathrm{N} 2.25 \mathrm{~g} \mathrm{~kg}^{-1}$; total P $0.75 \mathrm{~g} \mathrm{~kg}^{-1}$; total $\mathrm{K} 17.4 \mathrm{~g} \mathrm{~kg}^{-1}$; free $\mathrm{Fe}_{2} \mathrm{O}_{3} 16.3 \mathrm{~g} \mathrm{~kg}^{-1}$; and $\mathrm{CEC}$ $21.6 \mathrm{cmol} \mathrm{kg}^{-1}$.

\subsection{Arbuscular mycorrhizal fungus and host plants}

The AM fungus Glomus caledonium was isolated from calcareous soil collected from Henan province in China. The inoculum consisted of plants roots and soil derived from pot cultures with mung bean (Phaseolus radiatus) as host plant. Alfalfa (Medicago sativa) was selected as the test plant.

\subsection{Pot experiment}

The agricultural soil was sterilized and artificially contaminated with benzo $[a]$ pyrene $(\mathrm{B}[a] \mathrm{P})$. There were four treatments: control (no $\mathrm{B}[a] \mathrm{P})$ and $\mathrm{B}[a] \mathrm{P}$ applied at rates of 1,10 and $100 \mathrm{mg} \mathrm{kg}^{-1}$ (dry matter basis). $\mathrm{B}[a] \mathrm{P}$ was dissolved in acetone and mixed with $1 \%$ of the test soil. The acetone was evaporated in a fume cupboard for 2 days, then the soil was mixed with the remaining unpolluted soil and was shaken twice daily (for $20 \mathrm{~min}$ on each occassion) to ensure uniform distribution of the $\mathrm{B}[a] \mathrm{P}$.

After the samples were mixed, air-dried soil equivalent to $90 \mathrm{~g}$ was placed in each pot, about 5\% AM fungal inoculum was applied and a further $60 \mathrm{~g}$ soil was put on the surface of the pot. Noninoculated pots were also established using sterile inoculum. Thus, there were four rates of $\mathrm{B}[a] \mathrm{P}$ (including 0 rate controls) $\times 2$ mycorrhiza treatments (mycorrhizal and non-mycorrhizal) $\times 5$ harvest times $(30,40,50,60$ and 90 days $) \times 2$ 
planted (planted alfalfa and without alfalfa) $\times 3$ replicates, giving a total of 240 pots in a fully randomized design. The soil moisture content was adjusted to about $70 \%$ of the water-holding capacity (WHC) and the pots were incubated in a growth chamber for 7 days. Alfalfa seeds were sterilized in $30 \%(\mathrm{v} / \mathrm{v}) \mathrm{H}_{2} \mathrm{O}_{2}$ for $20 \mathrm{~min}$ and washed three times with distilled water. Fifteen seeds were sown in three of the six replicates and the seedlings were thinned to 10 seedlings after germination. The growth conditions were: $25^{\circ} \mathrm{C}$ during a 12-h day and at $20^{\circ} \mathrm{C}$ during a $12-\mathrm{h}$ night. The light intensity was 4500-7300 lux and the soil was watered and adjusted to $70 \%$ of WHC by weight on a daily basis.

The soil samples were air dried in the dark and the plants were weighed to determine their fresh biomass. The percentage of root length colonized by the AM fungus was determined on 100 root segments $(1 \mathrm{~cm}$ each) after staining by the method of Phillips and Hayman (1970). Root pieces were mounted on glass slides and examined under $\times 40$ magnification with a compound microscope (Leica Gallen III). Colonization was determined according to the method of Biermann \& Linderman (1981) and expressed as the percent of each root segment length that was colonized.

PAHs were determined followed the method described by Song et al. (1995). Soil polyphenol oxidase activity was measured using standard colorimetric methods (Dick et al. 1988) and soil dehydrogenase activity was determined using the TTC method described by Casida et al. (1964). Data were tested statistically by analysis of variance.

\section{Results and discussion}

\subsection{Mycorrhizal colonization of alfalfa roots in soil spiked with $B[a] P$}

Mycorrhizal colonization of alfalfa was not significantly affected by the addition of $\mathrm{B}[a] \mathrm{P}$ up to $10 \mathrm{mg} \mathrm{kg}^{-1}$. The proportion of root length colonized in the controls and $\mathrm{B}[a] \mathrm{P}$ application rates of 1 and $10 \mathrm{mg} \mathrm{kg}^{-1}$ were all significantly higher than in $\mathrm{B}[a] \mathrm{P}$ applied at $100 \mathrm{mg} \mathrm{kg}^{-1}(p<0.05)$ (Figure 1). Our results are similar to those of Leyval \& Binet (1998) who found that the indigenous AM population was not significantly affected by the addition of anthracene up to $10 \mathrm{mg} \mathrm{kg}^{-1}$. The absence of AM fungal propagules in contaminated soil implies that there is a level of PAHs or of some other compounds in the soil inhibiting colonization or survival of propagules if colonization has been successful. The presence and activity of AM fungal propagules should be considered in methods designed to modify the rhizosphere for remediation of contaminated soils. The highest concentration of $\mathrm{B}[a] \mathrm{P}$ tested restrained the growth of the AM fungus but the lower concentrations of $\mathrm{B}[a] \mathrm{P}$ did not affect the growth of the AM fungus.

\subsection{Soil enzyme activity}

\subsubsection{Polyphenol oxidase in soil}

Changes in enzyme activity in soil reflect the degradation activity of soil microorganisms and plant roots. Polyphenol oxidase is an important oxidoreductase in soils and can catalyse the degradation

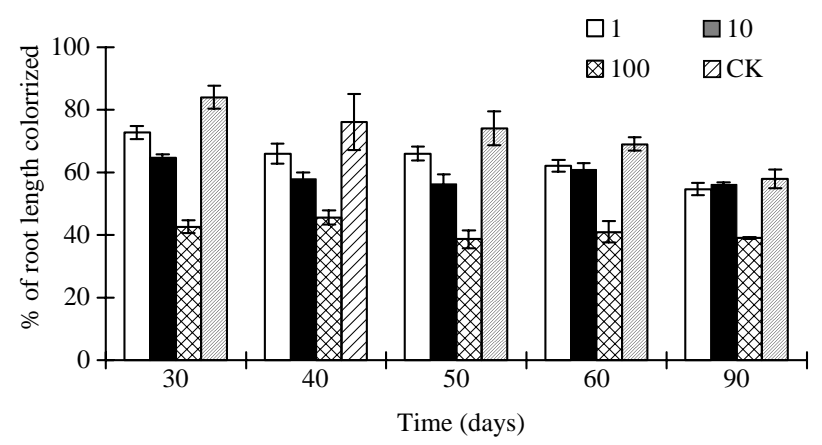

Fig. 1. Proportion (\%) of root length of mycorrhizal roots of alfalfa colonized in a soil spiked with B[a]P. Note: $1: 1 \mathrm{mg} \mathrm{kg}^{-1} ; 10$ : $10 \mathrm{mg} \mathrm{kg}^{-1} ; 100: 100 \mathrm{mg} \mathrm{kg}^{-1}$; CK: control, the same below. The error bars represent the standard deviation of triplicate experiments. 

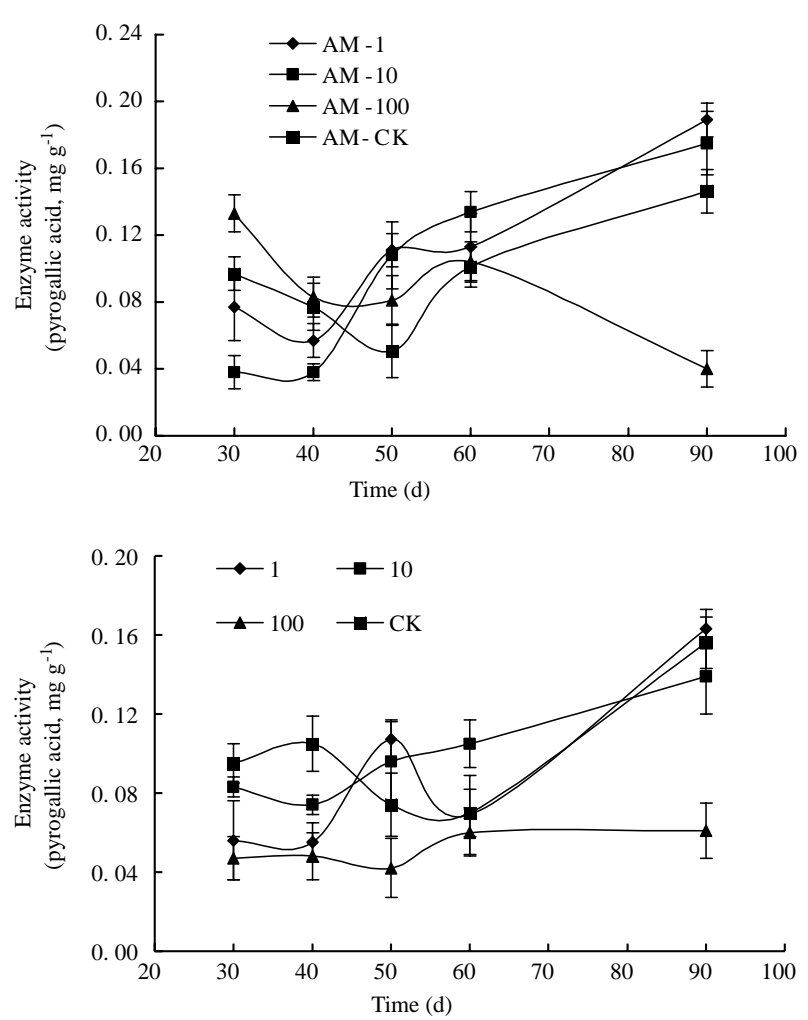

Fig. 2. Changes in polyphenol oxidase activity in soil. The $Y$-axis values in the figure are the differences between unplanted soil and soil planted with alfalfa. Note: AM-1: $1 \mathrm{mg} \mathrm{kg}^{-1}$ inoculated AM fungi; AM-10: $10 \mathrm{mg} \mathrm{kg}$-1 inoculated AM fungi; AM-100: $100 \mathrm{mg} \mathrm{kg}^{-1}$ inoculated AM fungi; AM-CK: CK inoculated AM fungi, the same below. The error bars represent the standard deviation of triplicate experiments.

and transformation processes of aromatic compounds (Andres \& John 2000). Figure 2 shows that there was no significant difference in enzyme activity among the treatments within the first 60 days of the experiment. However, at later stages the soil polyphenol oxidase activity following addition of low and intermediate levels of $\mathrm{B}[a] \mathrm{P}$ was significantly higher than that following the highest application rate $(p<0.05)$. AM fungal colonization had no effect on enzyme activity.

Plant roots can enhance the dissipation of organic pollutants in soils, and this has been mainly attributed to supply of root exudates for co-metabolic processes (Yoshitomi \& Shann 2001). When plant roots are stressed, e.g. in PAH-contaminated soil, the plants can exude certain enzymes to degrade or transform the pollutants. Studies have revealed a range of phenol oxidizing enzyme activities, including tyrosinase (EC 1.14.18.1), catechol oxidase (EC 1.10.3.1), ascorbate oxidase (EC 1.10.3.3) and laccase (EC
1.10.3.2) associated with symbiotic AM fungal mycelia in soils with organic pollutants (Bending \& Tead 1995; Colpaert \& van Laere 1996; Gramss 1997; Timonen \& Sen 1998). Elevated non-specific peroxidase (EC 1.11.1.7) and manganese peroxidase (EC 1.11.1.13) activities have also been recorded for soils colonized by AM fungal mycelia compared to equivalent uncolonized soil (Griffiths \& Caldwell 1992; Gramss 1997). Enzyme activities were associated with AM fungi, but it is difficult to separate enzyme activities produced by the AM fungi from those resulting from changes to the rhizosphere microflora that may be facilitated by the activities of the AM hyphae or those that utilize hyphal biomass or exudates as substrates.

\subsubsection{Dehydrogenase activity}

Figure 3 shows that there was no significant difference in dehydrogenase activity among the treatments during the first 30 days of plant growth. After 40 days the dehydrogenase activity 

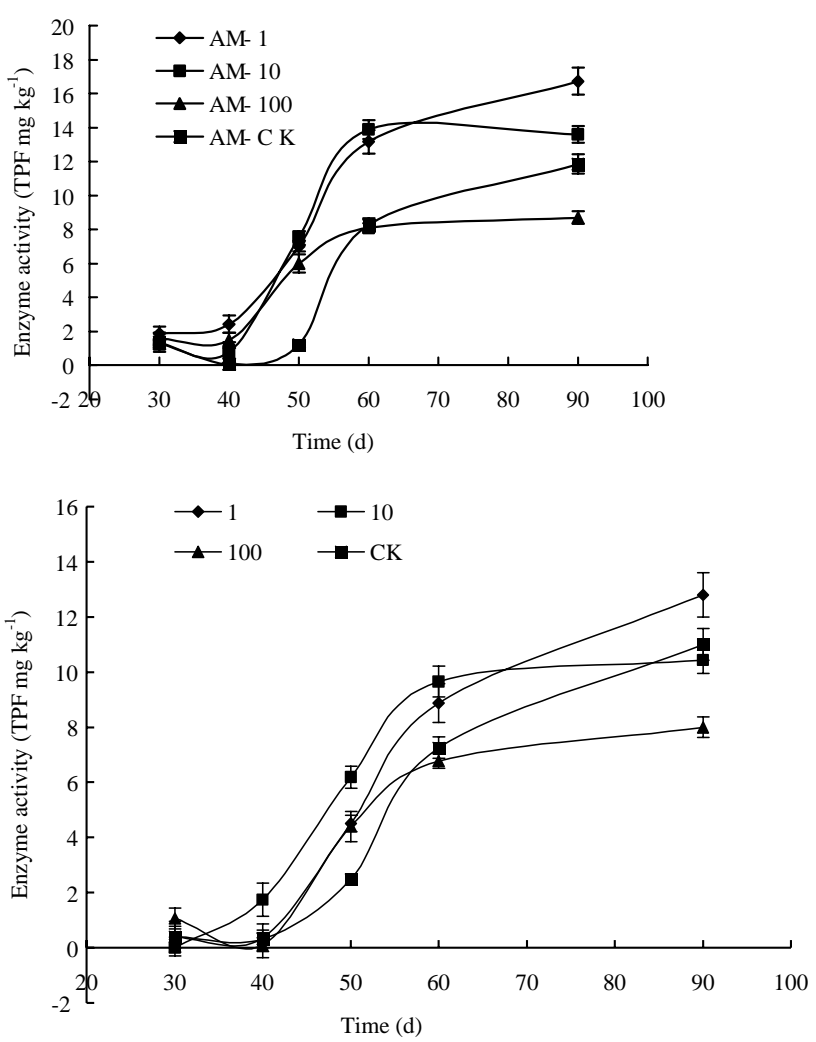

Fig. 3. Changes in dehydrogenase activity in soil. The $Y$-axis values in the figure are the differences between unplanted soil and soil planted with alfalfa. The error bars represent the standard deviation of triplicate experiments.

under low and intermediate rates of the PAH was significantly higher than at the highest application rate $(p<0.05)$. After 50 days the enzyme activity at the lowest $\mathrm{B}[a] \mathrm{P}$ application rate was significantly higher than the intermediate and highest rates of $\mathrm{B}[a] \mathrm{P}$, and the dehydrogenase activity at the intermediate rate of $\mathrm{B}[a] \mathrm{P}$ was also significantly higher than the highest rate of $\mathrm{B}[a] \mathrm{P}$ $(p<0.05)$. After 50 days the enzyme activity in soil inoculated with AM fungi was also significantly higher than in non-inoculated soil. This indicates that the highest concentration $\mathrm{B}[a] \mathrm{P}$ restrained dehydrogenase activity, but when AM fungi were present, enzyme activity was enhanced and $\mathrm{B}[a] \mathrm{P}$ degradation increased in the soil.

\subsection{Extractable $B[a] P$ concentration in soil}

\subsubsection{Extractable $B[a] P$ concentration with $A M$} fungal inoculation

Figure 4 shows that the extractable concentration of $\mathrm{B}[a] \mathrm{P}$ in soils gradually decreased with incuba- tion. In three treatments, extractable $\mathrm{B}[a] \mathrm{P}$ reduced rapidly during the first 30 days, then the degradation rate slowed down. When the AM fungus was present, the microorganisms in soil may take part in the degradation of $\mathrm{B}[a] \mathrm{P}$, so the extractable of $\mathrm{B}[a] \mathrm{P}$ concentration decreased quickly. The results indicated that alfalfa can also accelerate the degradation of $\mathrm{B}[a] \mathrm{P}$ in the soil, because in the three application levels, the degradation rate of $\mathrm{B}[a] \mathrm{P}$ in the treatments with planted alfalfa was significantly higher than in the treatments without alfalfa $(p<0.05)$. Over the 90-day growth period the degradation rate of $\mathrm{B}[a] \mathrm{P}$ added at rates of 1,10 and $100 \mathrm{mg} \mathrm{kg}^{-1}$ treatments with alfalfa present were 86,87 and $57 \%$, respectively; whereas the $\mathrm{B}[a] \mathrm{P}$ degradation rates in unplanted soils were 53, 53 and $33 \%$.

\subsubsection{Extractable $B[a] P$ concentration} in the absence of the AM fungus

Figure 5 shows that the changes in $\mathrm{B}[a] \mathrm{P}$ concentration in the uninoculated treatments were similar 

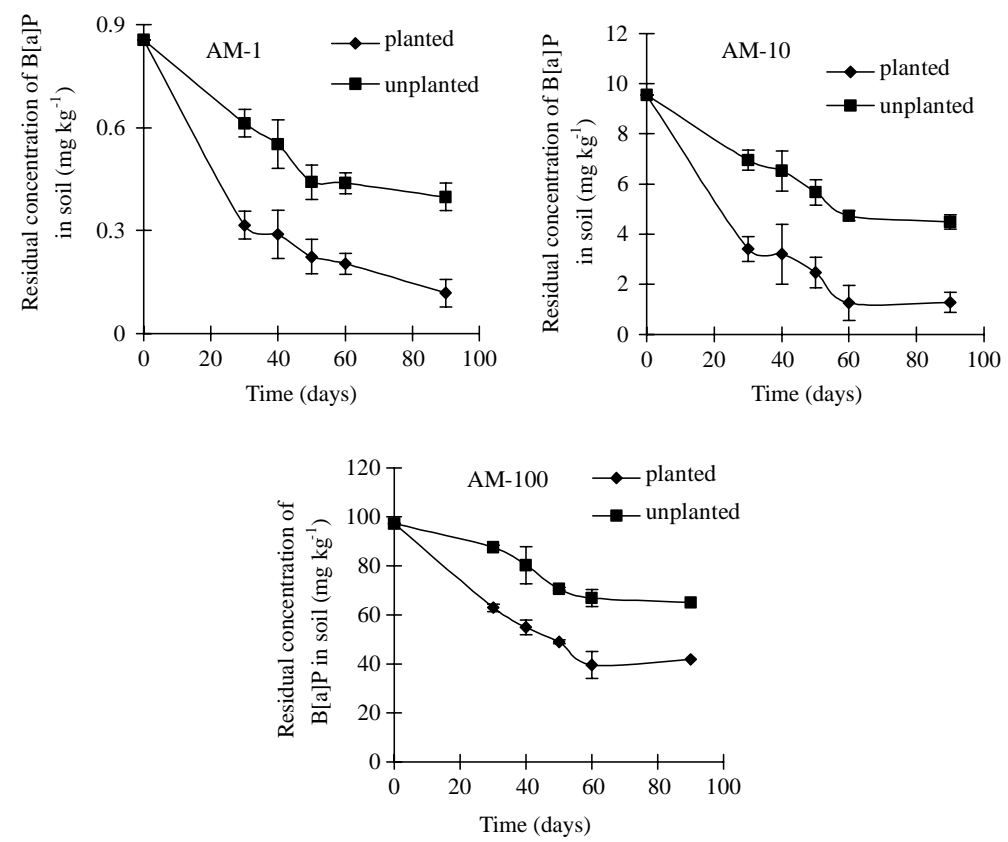

Fig. 4. Changes in extractable $\mathrm{B}[a] \mathrm{P}$ in soil inoculated with the arbuscular mycorrhizal fungus. The error bars represent the standard deviation of triplicate experiments.

to those in AMF-inoculated pots. However, the degradation rates of $\mathrm{B}[a] \mathrm{P}$ in non-mycorrhizal pots were lower than in mycorrhizal treatments. The degradation rate in the three treatments of $\mathrm{B}[a] \mathrm{P}$ spiked soil planted with alfalfa were: 76,78 and $53 \%$, respectively; and for unplanted pots were: 55 ,
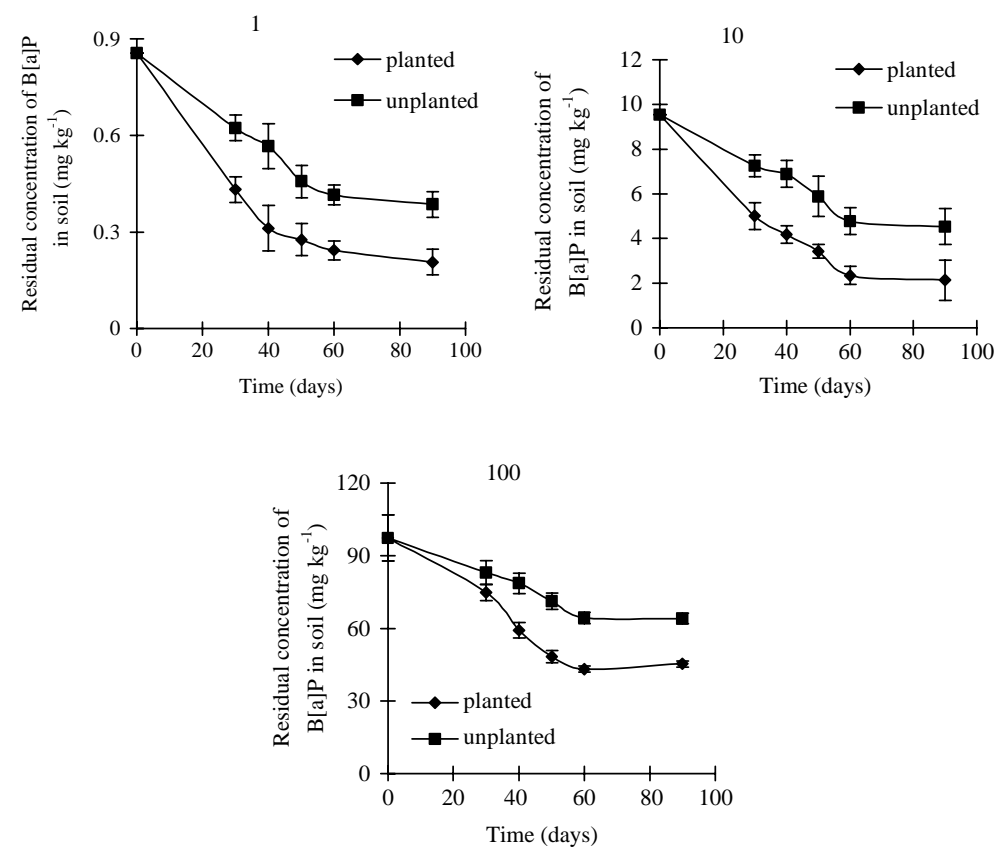

Fig. 5. Changes in extractable $\mathrm{B}[a] \mathrm{P}$ in soil without arbuscular mycorrhizal inoculation. The error bars represent the standard deviation of triplicate experiments. 
53 and $34 \%$. The figures also show that in the unplanted treatments, with the same $\mathrm{B}[a] \mathrm{P}$ concentration treatments, the degradation rate of $\mathrm{B}[a] \mathrm{P}$ between inoculated or non-inoculated pots was not different, showing that if there was no plant present, AM inoculation had no effect. The $\mathrm{B}[a] \mathrm{P}$ degradation rate in treatments of $\mathrm{B}[a] \mathrm{P}$ low and middle dosages were significantly higher than that of high $\mathrm{B}[a] \mathrm{P}$ dosage whether $\mathrm{AM}$ fungi were inoculated or not $(p<0.05)$. The results of the AM frequency (\%) of mycorrhizal roots of alfalfa and enzyme activity indicate that the high concentration $\mathrm{B}[a] \mathrm{P}$ was toxic to the $\mathrm{AM}$ fungus and thus affected the degradation of $\mathrm{B}[a] \mathrm{P}$ in soil.

Table 1 shows that the difference in $\mathrm{B}[a] \mathrm{P}$ concentration between unplanted soil and soil planted with alfalfa reflected the enhanced degradation of $\mathrm{B}[a] \mathrm{P}$ by alfalfa. Table 1 also shows the difference in degradation rate between the inoculated and uninoculated plants. In general, AM inoculation significantly enhanced $\mathrm{B}[a] \mathrm{P}$ degradation in the soil and the enhancement was greatest under the highest $\mathrm{B}[a] \mathrm{P}$ application rate.

Previous experiments with PAHs such as anthracene and pyrene (Schwab \& Banks 1994; Günther et al. 1996; Reilley et al. 1996) showed a very rapid dissipation of these compounds in the rhizosphere of several plants in the early stages (40 days) followed by slower rates. These authors also reported that degradation of pyrene was much faster in rhizosphere soil than in bulk soil. However, these experiments were performed with a mixture of only 2-4 PAHs. Binet et al. (2000) studied the fate of eight PAHs (3-6 rings) in the rhizosphere, and showed that ryegrass was able to accelerate the dissipation of a range of PAHs, including 5 and 6 ring PAHs such as dibenzo $(a, h)$ anthracene nad benzo $(g, h, I)$ perylene which have a low solubility and bioavailability. Their results also showed that the decrease in total extractable PAHs in the rhizosphere was higher in an experiment without soil ageing $(66 \%)$ than one with soil ageing. This difference could be due to the decreased bioavailability of the PAHs with the ageing process (Hatzinger \& Alexander 1995). Their results also showed that the ryegrass rhizosphere was able to improve dissipation of 3-6-ring PAHs, but that the dissipation was higher for 3-ring PAHs (phenanthrene and anthracene) than for the other high molecular weight compounds, confirming that they were more recalcitrant.

The AM fungi are of particular importance when plants are under environmental stresses such as water- or salt-stress (Sylvia \& Williams 1992). AM fungi have been shown to improve water uptake by plants (Sylvia \& Williams 1992), thus they may be crucial for water uptake in PAHpolluted soils. In this respect, mycorrhizal fungi producing dense and long extraradical hyphae may be particularly efficient in degrading PAHs in soils. Cabello (1997) showed that mycorrhizal colonization decreased significantly in hydrocarbon-polluted soils in comparison with a non-polluted soil. The effect of AM fungi on the

Table 1. Difference in extractable $\mathrm{B}[a] \mathrm{P}$ concentration $\left(\mathrm{mg} \mathrm{kg}^{-1}\right.$ ) between unplanted soil and soil planted with alfalfa under inoculation with and without AM fungi.

\begin{tabular}{|c|c|c|c|c|c|c|c|}
\hline \multirow[t]{2}{*}{ Added $\mathrm{B}[a] \mathrm{P}\left(\mathrm{mg} \mathrm{kg}^{-1}\right)$} & \multicolumn{7}{|l|}{ Time (days) } \\
\hline & AM fungus ${ }^{\mathrm{a}}$ & 0 & 30 & 40 & 50 & 60 & 90 \\
\hline \multirow[t]{2}{*}{1} & No & 0 & $0.19^{\mathrm{b}}$ & 0.26 & 0.18 & 0.17 & 0.18 \\
\hline & Inoculated & 0 & $0.30^{\mathrm{c}}$ & 0.26 & 0.22 & 0.24 & 0.28 \\
\hline \multirow[t]{2}{*}{10} & No & 0 & 2.24 & 2.71 & 2.45 & 2.43 & 2.40 \\
\hline & Inoculated & 0 & 3.53 & 3.32 & 3.20 & 3.47 & 3.20 \\
\hline \multirow[t]{2}{*}{100} & No & 0 & 8.11 & 19.47 & 22.96 & 21.13 & 18.73 \\
\hline & Inoculated & 0 & 24.63 & 25.33 & 26.60 & 27.42 & 23.33 \\
\hline
\end{tabular}

\footnotetext{
${ }^{a}$ No: no inoculated AM fungi; inoculated: inoculated with AM fungi.

${ }^{\mathrm{b}} \mathrm{A}$ difference in soil extractable $\mathrm{B}[a] \mathrm{P}$ concentration between unplanted and planted treatments under condition without AM fungi.

${ }^{\mathrm{c}} \mathrm{A}$ difference in soil extractable $\mathrm{B}[a] \mathrm{P}$ concentration between unplanted and planted treatments under condition with AM fungi inoculation.
} 
dissipation of organic pollutants has mainly been attributed to increased microbial numbers and selection of specialized microbial communities in the mycorrhizosphere (Reilley et al. 1996; Banks et al. 1999). Some studies have shown that the numbers of microorganisms in the mycorrhizosphere were as much as 1000 times those in the non-mycorrhizosphere, and that the microorganisms play an important role in the dissipation of organic pollutants in soils (Andrew et al. 2000). Moreover, AM fungi also release enzymes which may enhance the degradation of organic pollutants. The results of Leyval \& Binet (1998) indicate that AM fungi may improve plant survival in a PAH-polluted soil and the degradation rate of PAHs in contaminated soil with AM fungal inoculation were significantly higher than without AM fungal inoculation.

\section{Summaries}

The colonization rate of mycorrhizal roots of alfalfa was not significantly affected by the addition of $\mathrm{B}[a] \mathrm{P}$ up to $10 \mathrm{mg} \mathrm{kg}^{-1}$ during plant growth, but was significantly lower in the highest concentration of $\mathrm{B}[a] \mathrm{P}\left(100 \mathrm{mg} \mathrm{kg}^{-1}\right)$ than the lower $\mathrm{B}[a] \mathrm{P}$ concentrations $(p<0.05)$.

There was no difference in polyphenol oxidase and dehydrogenase activities among the control, 1 , and $10 \mathrm{mg} \mathrm{kg}^{-1} \mathrm{~B}[a] \mathrm{P}$ treatments but when $100 \mathrm{mg} \mathrm{kg}^{-1} \mathrm{~B}[a] \mathrm{P}$ was applied, polyphenol oxidase and dehydrogenase activities were significantly lower than in the other three treatments, and there was no difference between mycorrhizal and non-mycorrhizal treatments.

During the 90-day experimental period, concentrations of $\mathrm{B}[a] \mathrm{P}$ in alfalfa-planted soil were significantly lower than in unplanted soil $(p<0.05)$. In the 1,10 and $100 \mathrm{mg} \mathrm{kg}^{-1}$ $\mathrm{B}[a] \mathrm{P}$ treatments, the degradation rates of $\mathrm{B}[a] \mathrm{P}$ with non-mycorrhizal alfalfa were 76,78 and 53\%, respectively, and with mycorrhizal plants were 86, 87 and 57\%. The degradation rates in unplanted treatments were significantly lower than planted soil, and the degradation rates in medium and low $\mathrm{B}[a] \mathrm{P}$ treatments were significantly higher than at the high $\mathrm{B}[a] \mathrm{P}$ concentration.

\section{Acknowledgements}

We are grateful for grant-aided support from the Natural Science Foundation of China (no. 40031010), the Major State Basic Research and Development of the People's Republic of China (2002CB410809), we are also grateful to Joint Open Laboratory of Soil and Environment of the Institute of Soil Science, Chinese Academy of Science for their financial support.

\section{References cited}

Andrew AM, John WG. 2000 Ectomycorrhizas-extending the capabilities of rhizosphere remediation. Soil Biol Biochem 32, 1475-1484.

Aprill W, Sims RC. 1990 Evaluation of the use of prairie grasses for stimulating polycyclic aromatic hydrocarbons treatment in soil. Chemosphere 20, 253-256.

Banks M.K, Lee E, Schwab AP. 1999 Evaluation of dissipation mechanisms for benzo[ $a]$ pyrene in the rhizosphere of tall fescue. J Environ Qual 28, 294-298.

Bending GD, Read DJ. 1995 The structure and function of the vegetative mycelium of ectomycorrhizal. VI. Activities of nutrient mobilizing enzymes in birch litter colonized by Paxillus involutus (Fr.) Fr. New Phytol 130, 401-409.

Biermann B, Linderman R. 1981 Quantifying vesicular-arbuscular mycorrhizae: proposed method towards standardization. New Phytol 87, 63-67.

Binet P, Portal JM, Leyval C. 2000 Dissipation of 3-6-ring Polycyclic aromatic hydrocarbons in the rhizosphere of ryegrass. Soil Biol Biochem 32, 2011-2017.

Cabello MN. 1997 Hydrocarbon pollutant: its effect of on mative arbuscular mycorrhizal fungi (AMF). FEMS Microbiol Ecol 22, 233-236.

Casida LC, Klein DA Jr, Santoro T. 1964 Soil dehydrogenase activity. Soil Sci 98, 371-376.

Chaineau CH, Morel JL, Oudot J. 1996 Land treatment of oilbased drill cutting in an agricultural soil. J Environ Qual 25, 858-867.

Chaineau CH, Morel JL, Oudot J. 2000 Biodegradation of fuel oil hydrocarbons in the rhizosphere of maize. J Environ Qual 29, 569-578.

Colpaert JV, Van Laere A. 1996 A comparison of the extracellular enzyme activities of two ectomycorrhizal and leaf-saprotrophic basidiomyctes colonizing beech leaf litter. New Phytol 134, 133-141.

Dick RP, Myrold DD, Kerte EA. 1988 Soil polyphenol oxidase activity and its standard measure methods. Soil Sci Soc Am J 52, 512-516.

Donnelly PK, Fletcher JS. 1994 Potential use of mycorrhizal fungi as bioremediation agents. In Anderson TA, Coats JR, eds Bioremediation through Rhizosphere Technology. Washington, DC: American Chemical Society, pp. 95-99.

Edwards NT. 1983 Polycyclic aromatic hydrocarbons (PAHs) in the terrestrial environment - a review. J Environ Qual 12, $427-441$. 
Edwards NT. 1988 Assimilation and metabolism of polycyclic aromatic hydrocarbons by vegetation - an approach to this controversial issue and suggestions for future research. In Cook M, Dennis AJ, eds. Polycyclic Aromatic Hydrocarbons: A Decade of Progress. 10th Int SYMP Columbus, OH: Battelle Press, pp. 211-229.

Gramss G. 1997 Activity of oxidative enzymes in fungal mycelia from grassland and forest soils. J Basic Microbiol 37, 407423.

Griffiths RP, Caldwell BA. 1992 Mycorrhizal mat communities in forest soil. In Read DJ, Lewis DH, Fitter AH, Alexander IJ, eds. Mycorrhizas in Ecosystems, Wallingford: CAB International, pp. 98-105.

Guan YS. 1986 Soil Enzyme and its Research Methods. Peking: Agricultural Press (in Chinese).

Günther T, Dornberger U, Fritsche W. 1996 Effect of ryegrass on biodegradation of hydrocarbons in soil. Chemosphere 33, 203-215.

Harley JL, Smith SE. 1983 Mycorrhizal Symbiosis. New York: Academic Press.

Hatzinger PB, Alexander M. 1995 Effect of aging of chemicals in soil on their biodegradability and extractability. Environ Sci Technol 29, 537-545.

Joelle F, Corinne PG, Pascal EB, Jean LM. 2002 Soil-to-root transfer and translocation of polycyclic aromatic hydrocarbons by vegetables grown on industrial contaminated soils. $J$ Environ Qual 31, 1649-1656.

Jones KC, Stratford JA, Waterhouse KS, Furlong ET, Giger W, Hites RA, Schaffiner C, Johnson AE. 1989 Increase in the polynuclear aromatic hydrocarbon content of an agricultural soil over the last century. Environ Sci Technol 23, 95-101.

Lee E, Banks MK. 1993 Bioremediation of petroleum contaminated soil using vegetation: a microbial study. J Environ Sci Health 28, 2187-2198.

Leyval C, Binet P. 1998 Effect of Poluaromatic hydrocarbons in soil on arbuscular mycorrhizal plants. J Environ Qual 27, 402-407.

Leyval C, Turnau K, Haselwandter K. 1997 Interactions between heavy metals and mycorrhizal fungi in polluted soils: physiological, ecological and applied aspects. Mycorrhiza 7, 139-153.

Miller RM, Jastrow JD. 1992 The role of mycorrhizal fungi in soil conservation. In Bethlenfalvay GJ, Lindeman RG, eds. Mycorrhizae in Sustainable Agriculture. WI: ASA Spec. Publ. 54. ASA, CSSA, and SSSA, Madison, pp. 29-44.

Mosse B. 1973 Advances in the study of vesicular arbuscular mycorrhiza. Phytopathology 11, 171-196.

Phillips JM, Hayman DS. 1970 Improved procedures for clearing and staining parasitic and vesicular-arbuscular mycorrhizal fungi for rapid assessment of infection. Trans Br Mycol Soc 55, 158-161.

Qiu X, Shan SI, Kendall EW, Sorensen DL, Sims RC, Engelke MC. 1994 Grass-enhanced bioremediation for clay soils contaminated with polynuclear aromatic hydrocarbons. In Anderson TA, Coats JR, eds. Bioremediation through Rhizo- sphere Technology. Washington, DC: American Chemical Society, pp. 28-42.

Reilley KA, Banks MK, Schwab AP. 1996 Dissipation of polycyclic aromatic hydrocarbons in the rhizosphere. $J$ Environ Qual 25, 212-219.

Ryan K, Miya C, Mary K. 2000 Phenanthrene-degrader community dynamics in rhizosphere soil from a common annual grass. J Environ Qual 29, 584-592.

Schwab AP, Banks MK. 1994 Biologically mediated dissipation of polycyclic aromatic hydrocarbons in the root zone. In Anderson TA, Coats JR, eds. Bioremediation through Rhizosphere Technology. Washington, DC: American Chemical Society, pp. 132-141.

Shaw GR, Connell DC. 1994 Prediction and monitoring of the carcinogenicity of polycyclic aromatic compounds (PACs). Rev Environ Contam Toxicol 135, 1-62.

Sims RC, Overcash MR. 1983 Fate of polynuclear aromatic compounds (PNS's) in soil-plant system. Residue Rev $\mathbf{8 8}$, $1-68$.

Song YF, Ou ZQ, Sun TH, Yediler A, Lorinci G, Kettrup A, 1995 Analytical method of polycyclic aromatic hydrocarbons (PAHs) in soil and plant samples. Chin J Appl Ecol 6(1), 92-96.

Sylvia DM, Williams SE. 1992 Vesiculau-arbuscular mycorrhizao and environmental stresses. In Bethlenfalvay GJ, Linderman RG, eds. Mycorrhizao in Sustainable Agriculture. Madison, WI: ASA Spec. Publ. 54. ASA, CSSA, and SSSA; pp. 101-117.

Timonen S, Sen R. 1998 Heterogeneity of fungal and plant enzyme expressing in intact Scots pine-Suillus bovines and Paxillus involutus mycorrhizosphetes developed in natural forest humus. New Phytol 138, 355-366.

USEPA. 1985 Evaluation and estimation of potential carcinogenic risks of polynuclear aromatic hydrocarbons, Carcinogen Assessment, Office of Research and Development, USEPA, Washington, DC

Watkins JW, Sorensen DL, Sims RC. 1994 Volatilisation and mineralisation of naphthalene in soil-grass microcosms. In Anderson TA, Coats JR, eds. Bioremediation through Rhizosphere Technology. Washington, DC: American Chemical Society, pp. 123-131.

Wild SR, Jone KC. 1992 Organic chemicals entering agricultural soils in sewage sludges: screening for their potential to transfer to crop plants and livestock. Sci Total Environ 119, 85-119.

Wilson SC, Jones KC. 1993 Bioremediation of soil contaminated with polunuclear aromatic hydrocarbons (PAHs): a review. Environ Pollut 81, 229-249.

Wolfgang W. 2000 Polycyclic aromatic hydrocarbons (PAHs) in soil - a review. J Plant Nutr Soil Sci 163, 229-248.

Yoshitomi KJ, Shann JR. 2001 Corn (Zea mays L.) root exudates and their impact on ${ }^{14} \mathrm{C}$-pyrene mineralization. Soil Biol Biochem 33, 1769-1776.

Zaidi BR, Imam SH. 1999 Factors affection microbial degradation of polycyclic aromatic hydrocarbon phenanthrene in the Caribbean coastal water. Mar Pollut Bull 38, 737-742. 